\title{
Why primary obesity is a disease?
}

\author{
Antonino De Lorenzo ${ }^{1}$, Santo Gratteri ${ }^{2}$, Paola Gualtieri ${ }^{1 *} \mathbb{D}$, Andrea Cammarano ${ }^{1}$, Pierfrancesco Bertucci ${ }^{3}$ \\ and Laura Di Renzo ${ }^{1}$
}

\begin{abstract}
Obesity must be considered a real pathology. In the world wide, obesity represent one of the major public health issue associated with increased morbidity and mortality. Overweight or obesity, in fact, significantly increases the risk of contracting diseases, such as: arterial hypertension, dyslipidemia, type 2 diabetes mellitus, coronary heart disease, cerebral vasculopathy, gallbladder lithiasis, arthropathy, ovarian polycytosis, sleep apnea syndrome, and some neoplasms. Despite numerous informative campaigns, unfortunately, the fight against obesity does not seem to work: in the last years, the prevalence continued to increase. The progressive and rapid increase in the incidence of obesity, which has characterized most of the economically advanced countries in the last decade, has been the main stimulus for the research of the mechanisms underlying this pathology and the related disorders. The aims of this review is to provide a revision of the literature in order to define obesity as diseases, secondly to highlight the limits and the inaccuracy of common tools used for the diagnosis of obesity, and as a third thing to strengthen the concept of the complexity of obesity as a disease among political health care providers. Obesity may be viewed as a multifactorial pathology and chronic low-grade inflammatory disease. In fact, people affected by obesity have greater risk of developing comorbility and morbility, respect to healthy. Hence, the absolute therapeutic benefit is directly proportional to the basic risk. So, internationally interest on early diagnosis of obesity is growing to avoid under- and overdiagnosis consequences. Therefore, the consequences are an aggravation of the disease and an increase in obesity related pathology like diabetes, cardiovascular disease, and cancer. The most widely used parameter for diagnosis, body mass index (BMI) is not suitable for assessing the body fat. In fact, several studies demonstrate that BMI alone cannot define obesity, which consists not so much in weight gain as in excess fat mass. The use of suitable tools for the assessment of fat mass percentage combined with clinical and genetic analysis allowed to identify different phenotypes of obesity, which explain the various paradoxes of obesity. It is essential to adopt all possible strategies to be able to combat obesity, ameliorate the suffering of patients, and reduce the social and treatment costs of obesity.
\end{abstract}

Keywords: Obesity, Pathology, Phenotype, Obesity paradox

\section{Background}

World Health Organization (WHO) defined health as "a state of complete physical, mental and social well-being and not merely the absence of disease or infirmity", with the fundamental aim to expand the conceptual framework of nations health systems. However, despite the efforts to improve or preserve health, chronic degenerative diseases have increased [1].

\footnotetext{
*Correspondence: paola.gualtieri@uniroma2.it

1 Section of Clinical Nutrition and Nutrigenomic, Department of Biomedicine and Prevention, University of Rome Tor Vergata, Rome, Italy

Full list of author information is available at the end of the article
}

It therefore seems essential to define not only the state of health, but also of illness, in order to identify those indicators useful for promoting structural and environmental changes.

Diseases, that produce specific symptoms or affect a specific location, are defined as "deviations from the normal or healthy structure or function of a part, organ, or system of the body, caused by underlying etiologies, manifested by characteristic symptoms and signs, and resulting in pathologic consequences that affect health, feeling, or functioning" [2, 3].

The main requirement of defining the disease is its ability to accurately predict clinically relevant outcomes. It is important to underline that unclear 
definitions of illness result in inconsistent diagnoses and are of poor clinical utility.

In order to define a disease with certainty, it is necessary to know: the effects on incidence and prevalence of the disease itself; the changes to the natural history of the disease; the efficacy of the treatment; the benefits under conditions where the new definition will be used to determine the treatment threshold; the adverse effects including the psychological and economic ones; the usefulness of the definition of the disease on an individual and social level [4]. The possibility of not achieving all the listed requirements leads to a necessity of new definition [5].

The risk of an extension of the definitions of illness could be the inclusion of other pathologies, at different stages, already recognized.

In this case, both over- or underdiagnosis and a diagnostic error can led to no certainty of treatment efficacy. Due to this internationally interest on correct and early diagnosis is growing [6].

The critical point seems to lie in the lack of shared criteria for the definition of the disease and in the difficulty of the current ways of identifying and prevent any inappropriate changes [7].

However, from the point of view of a predictive and preventive medicine [8], the question that must be asked goes towards another direction. One has to wonder how the misdiagnosis or failure to early diagnosis of disease, such as obesity, aggravates the consequences in terms of morbidity and mortality and in health care costs, where correct diagnostic tools are available and personalized care is possible. A patient will benefit from the diagnosis of a disease only if it allows the understanding of symptoms or the risk of clinically relevant events, or if the patient can benefit from a specific treatment. In particular, the obesity problem seems to be the underdiagnosis rather than the overdiagnosis. In fact, about $30 \%$ of the people with obesity does not have a diagnosis because of the limit to evaluate the body fat content [9].

The aims of this review is to provide a revision of the literature in order to define obesity as diseases, secondly to highlight the limits and the inaccuracy of common tools used for the diagnosis of obesity, and as a third thing to strengthen the concept of the complexity of obesity as a disease among political health care providers.

\section{Obesity as disease and increased comorbidity risk}

Obesity is a real epidemic and a public health problem, defined by The Obesity Society (TOS) as a disease [10], and not only an underpinning of major chronic diseases, but a serious debilitating condition in its own right [11].
Obesity is a multifactorial pathology that can be related to an altered nutritional behavior or secondary to genetic, hypothalamic, iatrogenic or endocrine diseases [12].

At the base of obesity is adiposopathy (or "sick fat") defined as "pathologic adipose tissue anatomic/functional disturbances promoted by positive caloric balance in genetically and environmentally susceptible individuals that result in adverse endocrine and immune responses that may cause or worsen metabolic disease" [13].

Adiposopathy is sustained by adipocyte hypertrophy, visceral adiposity and/or ectopic fat deposition and secretion of hormones, like leptin, and proinflammatory protein, like the plethora of cytokines, that in turn may lead to metabolic disease [14].

Therefore, we can classified obesity as a primary disease since the adiposopathy determines the dysregulation of the metabolic pathways [15]. Metabolic diseases most associated with primary obesity contribute to atherosclerosis, hypertension, dyslipidemia, diabetes type II, hyperandrogenemia in women and hypoandrogenemia/ hyperestrogenemia in men [16].

There may be pathogenic immune and adiposopathic endocrine responses for the cardiovascular system or other systems. Sometimes, adiposopathy may cause atherosclerotic risk factors such as type 2 diabetes mellitus or dyslipidemia [17].

The diagnosis and treatment of obesity plays, therefore, an important role since this pathology is associated with an increased risk of numerous diseases and reduced life expectancy.

Pre-obesity or obesity significantly increases the risk of contracting and favoring the development of more than 200 chronic diseases [18], including but not limited to the following: type 2 diabetes mellitus (the risk of suffering from diabetes mellitus is 2.9 times higher in subjects with obesity, and the prevalence of diabetes is ten times greater in subjects with moderate obesity and thirty times in cases of excess of $135 \%$ of body weight compared to the ideal weight); cardiovascular diseases (CVD); hypertension (three-fold increase in risk of being affected by hypertension); dyslipidemia; coronary heart disease; gallbladder stones (three-fold increase in risk of being affected by gallbladder stones); obstructive sleep apnea syndrome; asthma; psychiatric diseases, including depression; polycystic ovary syndrome; nonalcoholic fatty liver disease; gastrointestinal reflux disease; osteoarthritis; some cancers. Among the most common tumors, obesity increases the risk of postmenopausal breast, endometrial, prostate, colorectal cancer and adenocarcinoma $[19,20]$. Several studies on children have shown that there has been an increased risk of diabetes, CVD, cancer, PolyCystic Ovary Syndrome [21-25]. 
Obesity is necessary not only related to metabolic consequences and major chronic diseases, as it can considered a serious debilitating condition by itself. Excess of body fat may be accompanied by structural and functional abnormalities that reduced quality of life, as gastrointestinal reflux disease, gallbladder disease, osteoarthritis, obstructive sleep apnea/obesity hypoventilation syndrome, psychological and eating behavior disorders, anxiety and depression, and physical performance [10]. Moreover, obesity has an impact on cognitive functioning and major depressive disorder (MDD), with negative effects and additive on the processing speed and executive function measurements, as highlighted by mood rating questionnaires and neuropsychological tests [26].

Significant correlation among body composition variables, as weight, BMI, total body fat, and eating disorders, according to Eating Disorder Inventory-2 (EDI-2) score [27].

Furthermore, the excess of body fat reduces mobility, walking endurance and physical performance, accompanied by sarcopenia [28], regardless of age but according to the inflammatory status and genetic predisposition $[29,30]$.

The most serious consequences of obesity on health are hypertension, diabetes, myocardial infarction and major cardiovascular events. In particular, diabetes, a consequence of caloric excess, shows a direct association with other comorbidities, such as hypertension which is positively correlated due to vessel damage [31]. For this reason, the prevalence of cardiovascular complications has reached $64 \%$ only in older American patients who are obese and diabetic [32]. Between America, Europe and Australia the prevalence of hypertension reaches $60-75 \%$ [33-36]. In obese patients with diabetes and hypertension the incidence of ischemic heart disease exceeded $30 \%$ [37]. Heart failure is a serious condition and very widespread in obese patients with diabetes and hypertension, the prevalence in America, Europe and Austria reached $15 \%$. In addition, the same category of patients presented with deep vein thrombosis and peripheral arteritis [38, 39].

In the obese, 30-day mortality after hospitalization for myocardial infarction reached $16 \%$ without diabetes [40] and $19 \%$ in those with diabetes [41]. Only in the US in 2012 there were over 110,000 deaths from cardiovascular disease [42].

Mortality due to comorbidities and to the increase in weight itself is a fact highlighted throughout the world in different populations [43]. This result suggests that preobesity and obesity alone are associated with increased mortality, thus bypassing the hypothesis that excess body fat in healthy subjects may play a metobolically protective role [44].

\section{Diagnostic methods and impact on prevalence of obesity}

According to the classification based on body mass index (BMI), the ratio between weight in kilograms and height in meters squared $\left(\mathrm{kg} / \mathrm{m}^{2}\right)$ [45], a patient is considered overweight for BMI values greater than $25 \mathrm{~kg} / \mathrm{m}^{2}$ and obesity is classified when BMI is greater than $30 \mathrm{~kg} / \mathrm{m}^{2}$ [46].

For example, in USA, among adult men, the prevalence of obesity is: Hispanic, $37.9 \%$; black, $38.0 \%$; white, $34.7 \%$; and Asian, $12.6 \%$. In women, the prevalence of obesity is: Hispanic, 46.9\%; black, 57.2\%; white, 38.2\%; and Asian, $12.4 \%$. In children and adolescents, the prevalence of obesity is $17.0 \%$ of 2 - to 19 -year-olds subjects, with males and females equally affected [47]. The prevalence of obesity among US children and adolescents is: Hispanic, 21.9\%; black, 19.5\%; white, 14.7\%; and Asian, 8.6\% [48].

However, if we analyze the definition of obesity of the WHO, which identifies it as "a condition in which percentage body fat (PBF) is increased to an extent in which health and well-being are impaired", we can state that it is defined by the expansion of the adipose tissue, rather than defining it solely on the basis of the increase in body weight [49]. The presence of obese subjects for BMI, or normal weight, with or without metabolic syndrome is a longstanding controversy. The research allowed to overcome this paradox with the introduction in the diagnosis of body composition, the evaluation of visceral fat, metabolic indices and genetic predisposition [50].

It is clear that the expansion of visceral and ectopic fat is a cardiovascular and metabolic risk factor that exceeds BMI. In clinical practice, measurements of visceral fat, adiposity, body composition and genetic/metabolic factors should be implemented to improve risk assessment and develop effective preventive and therapeutic strategies for high-risk obesity [51].

Therefore, BMI results limited and often unfit to discover hidden fat [52].

Obesity can be measured using direct and indirect measures of fatness other than BMI.

The body adiposity index has been found to be more sensitive to identify and classify obesity than the BMI [53]; however, it failed in the body fat estimation in populations with extreme amounts of fat [54].

Belarmino et al. validated a new anthropometric index to estimate the PBF, the Belarmino-Waitzberg (BeW) index, with a positive Pearson correlation $(r=0.74)$, a good accuracy $(\mathrm{Cb}=0.94)$, and a positive Lin's concordance correlation $(C C C=0.70)$ were observed comparing PBF estimated by air displacement plethysmography and BeW [55].

Anthropometric-based stratification is, however, prone to measurement errors. There are different limitations, 
such as age and ethnicities. Furthermore, these tools do not discriminate the types of visceral adiposity and the possible presence of metabolic risks.

In fact, as reported by Bray et al. and De Lorenzo et al. using BMI cutoff values to diagnose obesity approximately half of people with excess fat was missed, due to low sensitivity to identify adiposity $[9,47]$.

Therefore, it is necessary to use methods that accurately evaluate the amount of body fat (BF), fat free mass (FFM), skeletal muscle mass [56], the metabolically active body cell mass (BCM), bone mass, and the total amount of body water with the distribution of water compartments on large population samples [57].

The methods to estimate BF include, hydrostatic plethysmography, isotope dilution techniques, dual x-ray absorptiometry (DXA), skinfold method, bioelectrical impedance, magnetic resonance imaging, computed tomography scan and air displacement plethysmography [58-60].

Oliveros et al. from the Third National Health and Nutrition Examination Survey (NHANES III) tested the accuracy of BMI for diagnosing obesity in the adult general population using data from 13,601 individuals. Using bioimpedance analysis to calculate BF and BMI $>30 \mathrm{~kg} /$ $\mathrm{m}^{2}$ to define obesity, BMI had a very high specificity (97\%) but poor sensitivity (42\%) to detect obesity [52].

In a study of our group, we showed a wide range of PBF using dual energy $x$-ray absorptiometry (DXA) in people with normal BMI, ranging from 5.6 to $31.2 \%$ in men and from 4.6 to $51.1 \%$ among women. This underlines the main limitation of BMI, which cannot differentiate BF from lean mass, and central from peripheral fat [9].

De Lorenzo et al. comparing the classification of obesity according to the BMI with that according to the percentage of fat mass (25\% for men and $30 \%$ for women), showed a strong discrepancy between the two measurements. In a study conducted in Italy on 900 subjects, of both sexes, aged between 18 and 83 years, it emerged that $28 \%$ of the participants classified as normal weight only on the basis of the BMI values resulted in pre-obesity condition, i.e. with a PBF above $25 \%$ in men and $35 \%$ in women, while $5 \%$ had obesity, with a PBF $>30 \%$ in males and $>40 \%$ in females. $50 \%$ of overweight subjects based on BMI values were in a condition of obesity [61]. Similarly, on other 3258 Italian subjects, the percentage of obesity changed depending on the criterion adopted. According to the BMI, obesity affected the $32.3 \%$ of population while, according to the cut-off acceptable percentage of fat mass as a function of sex and age, $64 \%$ of the population was in obesity status [9].

Therefore, a new predictive equation for PBF was evaluated, that could be helpful to clinicians to assess easily the body fat of their patients. PBF equation is available online at the site: http://www.mat.uniroma2. it/ ricerca/biosta/PBFcalculator.html [62].

The above results demonstrate that BMI alone is not able to define obesity, which consists not so much in weight gain as in excess of BF.

To overcome the limit of anthropometric assessment, due to heterogeneity of obesity, the edmonton obesity staging system (EOSS) was applied, as a tool useful for clinical staging system [63]. EOSS divides the population with excess adiposity on an ordinal 5-point scale, taking into account the comorbidities linked to obesity: (1) no apparent risk factors; (2) presence of obesityrelated subclinical risk factors; (3) presence of established obesity-related chronic disease; (4) established end-organ damage; (5) severe disabilities. The possibility to predict mortality according to the EOSS was independent from BMI values. However, since EOSS cannot be used for a direct or indirect measure of adiposity, it represents only a prognostic system capable of integrating anthropometric indices [64].

To counter the increase in cases of obesity, the European Association for the Study of Obesity (EASO) has promoted various types of actions and has proposed the revision of the diagnostic criteria of the International Classification of Diseases ICD-11 [65]. In this context, the new definition of obesity as adiposity-based chronic disease $(A B C D)$, for wich the term "adiposopaty" means the whole represented by the total quantity of fat, its distribution, and the function of adipose tissue, fits well with the EASO's purposes [66]. Therefore, a diagnosis of $A B C D$ could allow a more specific analysis of the complications caused by the dysfunctional adipose tissue, with a greater possibility of effectiveness of the intervention.

It appears that BMI classification should be overcome in favor of a new classification based on physiopathological findings. Therefore, as suggested by Penny GordonLarsen and Steven B. Heymsfield, the best strategy to prevent and treat obesity, recognized as disease and not behaviour, is to define the heterogeneity of obesity and its complication [67].

A WHO expert committee concluded "there is no agreement on the cut-off points for the PBF that constitutes obesity" [45].

Anyway, current research suggests that obesity cutoff points of $\mathrm{PBF}$ are in the $23-25 \%$ range in men and $30-33-35 \%$ range in women [68].

Furthermore, transversal and longitudinal studies have documented sex and age-related changes in body composition, confirming an age-related remodeling of body composition with decreased skeletal muscle mass, both in tone and in trophism, and a corresponding increase in visceral and intermuscular adipose tissue [69]. 
In order to avoid erroneous classifications, the diagnosis and treatment of obesity cannot be separated from a careful general and nutritional history, from the objective examination, from the measurement of the biochemical and hormonal parameters, from the measurement of energy expenditure to rest and, above all, the evaluation of body composition, in particular of the percentage of fat mass.

PBF turns out to be a better tool, compared to BMI, for a correct diagnosis of obesity, universally valid.

Advantages and disadvantages of diagnostic measures and index are resumed as follow:

\section{Limits of weight and height}

In healthy adults, the fluctuations in weight are linked to daily physiological water, nutritional and evacuating changes of up to $2 \mathrm{~kg}$, without representing loss or gain of lean or fat mass. In pathological states, imbalances may be greater. For example, in hemodialysis the weight can vary from 1.6 to $1.9 \mathrm{~kg}$ up to a gain of $4.0 \mathrm{~kg}$ between sessions [70]. Therefore, the measurement of vertical stature is prevented by confounding factors such as abnormal hair or curvature of the spine such as idiopathic scoliosis or muscular dystrophy [71]. Also, the use of height reported by the subjects should not be used in clinical practice, as demonstrated by several studies, especially in older women, affected by vertebral collapse, which tend to overestimate an average of 2.3-5 cm [72]. For these reasons, weight and height measurement must always be carried out at the same time of day associated with a clinical evaluation of the individual [73].

\section{Limits of circumference and skinfolds}

The main limit of waist circumference and of waist/hip ratio is the impossibility of distinguish between subcutaneous and visceral adipose tissue at the abdominal level. This distinction is fundamental considering that visceral adipose tissue, compared to the subcutaneous tissue, is related to a high metabolic risk. The reference values (cut-off) are specific for country and population, but not specific for ages; this is a limit, as waist circumference generally increases in both men and women with their age. The reliability of the folds is limited by several factors, such as the variability of the thickness of the subcutaneous adipose tissue, the inter-individual variability of the elastic properties of tissues and the impossibility of measuring too large skinfolds reduce accuracy, especially in the obese. Furthermore, a limitation is the assumption that the amount of subcutaneous fat reflects that of visceral fat [74].

\section{Limits of the body mass index (BMI)}

Although, BMI is significantly correlated with the amount of fat mass, measured with standard method, in the general population, the index loses predictability in the individual. Thus, individuals with the same BMI may have a significantly different fat mass [75]. The index, not including sex and age, tends to overestimate fat in young people and to underestimate it in the elderly. Since, the BMI does not evaluate individual body compartments. A value above the limits of normality is not always synonymous with an increase in fat mass: for example, an athlete could have a high BMI but a reduced fat mass and still be defined as overweight or obese [76].

\section{Advantages and disadvantages of bioimpedentiometry analysis (BIA)}

The BIA is characterized by simplicity of use, repeatability, low cost and invasiveness. Furthermore, this is recognized as a standard for the evaluation of the body cell mass. On the contrary, potential errors of impedance analysis are mainly due to an altered state of hydration and/or electrolyte balance that interfere with tissue impedance. Attention to pre-test, fasting and rest protocols is essential to ensure that the measurement obtained is as accurate as possible [77]. The use of BIA for the body composition in clinical practice is less accurate in the obese, nephrological and altered hydration patient. It is also important to remember that BIA was developed for the analysis of the body composition of healthy adults with normal and constant hydration. However, it must be pointed out that BIA can specifically recognize and measure only the conductive compartment of tissues. Moreover, the conductivity of the body's tissues is determined not only by hydration, but also by the limits imposed by the individual's body geometry, according to its phenotype. Body geometry is a key point. The overweight/obese phenotype, with mainly android fat distribution, moves away from the five-cylinder ideal model, and is more susceptible to errors in the estimation of body composition [78].

\section{Advantages and disadvantages of dual-energy X-ray absorptiometry (DXA) analysis}

The DXA analysis is the standard for the tri-compartmental body composition, fat mass, lean and bone. In addition, densitometric analysis allows evaluation on both whole and segmental bodies. The newly released software is able to extrapolate the visceral fat mass thus applying a body composition method to the evaluation of cardiovascular risk. The technical limits of DXA are the maximum weight limit $(200 \mathrm{~kg})$ and the restrictions for height and wide of the individual examined $(197 \times 66 \mathrm{~cm})$, 
compromise the accuracy of the measurement with DXA for subjects outside normality range. Moreover, specific algorithms are necessary for the estimation of fat mass hidden by the bone shadow cone. DXA does not provide an estimate of the hydration status, since it measures neither total water nor the hydration of lean mass. However, it remains to take into account inter-individual variability related to food and fluid intake, physical exercise and other physiological or pathological processes, which alter body water content [79].

\section{The "obesity paradox" (OP) and the "obesity phenotypes"}

The possibility of using increasingly precise and accurate biomarkers, useful for a precise diagnosis and a personalization of therapy, and the identification of paradoxes would seem to justify the doubts that lead to define overdiagnosis as the worst event of underestimation of the disease.

However, if we try to analyze the various paradoxes, we will see how often these may depend on the wrong methods used for the diagnosis itself.

Analyzing the risk factors and illness scoring systems that included BMI in their risk adjustment, as the Acute Physiology and Chronic Health Evaluation (APACHE) IV system [80], the Oxford Acute Severity of Illness Score (OASIS) [81], the Sequential Organ Failure Assessment (SOFA) score [82], and the Simplified Acute Physiology Score (SAPS) 3 [83], a counterintuitive epidemiological phenomenon is observed, defined as "re-verse epidemiology" or "obesity paradox." [84]. In the case which the diagnosis of malnutrition, due to excess of body fat mass and/or a defect of body lean mass, does not take into account the equilibrium and cross-talk between fat and muscle mass, patients with morbid or severe obesity tend to have lower morbility, and hospital mortality rates than patients with normal weight or underweight [85]. Potential confounders may be relevant to explain this paradox. According to Deliberato et al. this depends on the fact that weight itself, and therefore the BMI, might not be explain the extreme obesity [86].

The "obesity paradox" (OP) could be explained by the fact that the classification with BMI obesity definition groups together, in the same category, subjects with different clinical and biochemical characteristics. In multiple investigations, obesity measured by BMI and various other indices has been linked to the survival of heart failure (HF) [87].

In a large population of 7499 individuals with symptomatic HF, with preserved and reduced ejection fraction, there is an improvement in the quality of life and a reduction in the risk of mortality in subjects with obesity. The group with the highest BMI $\left(35 \mathrm{~kg} / \mathrm{m}^{2}\right)$ had similar risk to those with BMI $30.0-34.9 \mathrm{~kg} / \mathrm{m}^{2}$ [88].

Moreover, lower BMI was associated with a greater risk of all death causes in patients without edema, because edema increased BMI based on fluid excess rather than solid tissue mass [89].

The BMI classifies in the same categories individuals with different clinical and biochemical characteristics without taking into account inflammatory status of visceral adipose tissue, related to the risk of CVD [90]. Hypertrophic or apoptotic adipocytes in individuals with obesity increased the pro-inflammatory status, due to the secretion of several molecules such as leptin, resistin, interleukin 6 (IL-6) and tumor necrosis factor- $\alpha$ (TNF- $\alpha$ ) that can activate M1 macro-phage-response [91, 92]. Therefore, Vecchiè et al. highlighted the need for an approach that consider the heterogeneity of obesity [93]. This is explained by the fact that BMI is not a parameter that can be used for diagnosis, nor for fat distribution, or based on age and gender. In fact, the amount of adipose tissue and distribution of adiposity were significantly related to adverse cardiac remodeling and adverse hemodynamics [94].

The OP does not only occur in CVD patients, but also exists in other chronic diseases.

A potential protective effect of high BMI in terms of improvement in kidney disease and end-stage renal disease was evaluated. With a glomerular filtration rate $<60 \mathrm{ml} / \mathrm{min} / 1.73 \mathrm{~m}^{2}$ or presence of microalbuminuria, a BMI of $18.5-22 \mathrm{~kg} / \mathrm{m}^{2}$ was associated with a higher risk of death [95].

Kalantar-Zadeh et al. demonstrated that survival depends on muscle mass. Long term, muscle gain with a loss of total body weight is better than weight gain with loss of muscle mass [96]. Patients with obesity are less inclined to develop cachexia, and protein-energy wasting. Moreover, less intradialytic hypotension was observed [95].

Many papers confirmed the existence of an OP in type 2 diabetes mellitus [97], underling the U-shaped association between mortality and BMI $[98,99]$.

All this does not mean that patients with chronic degenerative diseases have to weigh down [100]. But, it is rather important to evaluate body composition, the person's weight history, the type of previous or in course medication and behavioral therapy (i.e., diet and physical activity changes). All this because it is possible that higher mortality in normal weight subjects may be associated with low muscle mass and not low adiposity [101].

The existence of many "obesity phenotypes" with different metabolic and CVD associated risk due to physical and life-style features, underlining the heterogeneity of 
obesity, which recognizes numerous possible etiologies, could explain in part the described paradoxes [76, 93].

De Lorenzo et al. [59] classified different phenotypes of obesity: the normal-weight obesity (NWO); the metabolically healthy obesity (MHO); the metabolically unhealthy obesity (MUO).

The metabolic disorders were evaluated according to National Cholesterol Education Program Adult Treatment Panel III (NCEP ATP III) to distinguish MHO from MUO, and according the International Diabetes Federation (IDF) criteria for the differential diagnosis between NWO syndrome and MONW [102].

Furthermore, an additional phenotype of 'super-obesity', that designate patients with a $\mathrm{BMI} \geq 50$ associated with a greater burden of obesity-related comorbidities, representing about $5-10 \%$ of all obese persons, was highlighted [103]. Antonini-Canterin et al. demonstrated that superobesity was associated with insulin resistance and a worse impact on cardiac remodeling and left ventricular diastolic function [104].

Metabolically healthy subjects also exist in the super obese phenotype. In particular, it has been shown that men suffering from superobesity find themselves in a better metabolic condition than women; the beneficial metabolic situation could be explained by sex hormone changes that favor gynoid fat distribution [105].

In particular, two sub-classes of NWO were described [52]: the metabolically healthy normal weight obesity, typical of Normal Weight Obese (NWO) syndrome [91], with high CVD risk indices, and the normal weight obesity associated with Metabolic Syndrome (MetS) and insulin resistance [106] defined as metabolically obese normal weight (MONW) [107].

Therefore, to identify subjects with cardiometabolic risk, it is crucial to evaluate not only the BMI but also the total amount of $\mathrm{BF}$, the regional distribution of fat and ectopic fat depots, due to the secretion of different adipokines and other bioactive substances that are related to metabolic disorders [108].

MHO individuals show a $\mathrm{BMI}>30$, a $\mathrm{PBF}>30 \%$, and waist circumference $>90 \mathrm{~cm}$, with normal lipid and blood pressure profile, and a good insulin sensitivity [109]. In MHOs, the higher levels of insulin sensitivity and inflammation may be due in part to a reduction in visceral adiposity compared to a large amount of total fat [110]. Blood pressure is normal, serum lipid profile is well preserved, the degree of inflammation is low and no abnormal liver function is observed; MHO individuals are usually young, with good levels of physical activity and a good dietary habit [111].

Other metabolic, genetic or behavioral factors could be involved and should be investigated with appropriate studies [112]. Furthermore, many doubts remain regarding the understanding of the factors contributing to the protective profile of these individuals [113]. $\mathrm{MHO}$ and subclinical atherosclerosis are mediated by metabolic risk factors, which are well below as effectively considered as abnormal in routine lab tests [114].

It follows that these individuals cannot be considered in an optimal state, but rather that they present a lower risk than the subjects with obesity "at risk", but still greater than in the general population.

NWO and MONW subjects are mostly unaware that they are in the risk group, and MHO individuals need medical attention and periodic weight management because of obesity-related complications [115-117].

MONW are subjects with weight and BMI in the normal range, but with high PBF and a cluster of abnormalities related to obesity. These individuals are usually young and show premature signs of insulin resistance, hyperinsulinemia, dyslipidemia that could be associated with an increased risk of diabetes and CVD [107].

In 2006, our group for the first time described the NWO syndrome with metabolic abnormalities. This syndrome is characterized by normal weight individuals but genetically obesity, in an early low-grade inflammatory state [118].

The PBF is higher than $30 \%$, with is a significant reduction of the lean mass, equal to at least $1.5 \mathrm{~kg}$ (FFM $\mathrm{kg}$ ), particularly in the lower limbs muscle mass [30]. The effects of the body composition on the Resting Metabolic Rate, assessed by indirect calorimetry, result in a reduction of about $200 \mathrm{kcal}$ per day, which can be explained by a reduction of the metabolically active lean mass. NWO individuals exhibit a narrow inverse relationship between cardiovascular risk indices and body fat distribution $[119,120]$.

The unified theory explained the relationship between inflammation and chronic diseases, but it is essential evaluate how genetic characteristics interact with the exposition to environmental agents, defining the phenotype [121].

They have high circulating levels of TNF- $\alpha$, interleukins as IL- $1 \alpha$, IL- $1 \beta$ and IL-8 [122], and an oxidative stress related to metabolic abnormalities [123].

NWO show an alteration of a cluster of genes linked to inflammation and aging. NWO women have specific and characteristic polymorphisms of IL-15 receptor alpha subunit and $677 \mathrm{C} / \mathrm{T}$ methylenetetrahydrofolate reductase (MTHFR) genes, which increase the risk of breast cancer, carcinoma of the colon and sarcopenia [119].

A polymorphism in the second intron of the IL-1 receptor antagonist gene is associated with NWO syndrome, predisposing to ovarian, pancreatic, cervical and gastric carcinoma risk [123]. 
The -308 G/A TNF- $\alpha$ polymorphisms increased the prevalence of sarcopenia in NWO: considering appendicular skeletal muscle mass index values, $4.21 \%$ of NWO subjects were sarcopenic [30].

Investigating the allelic frequency of the TP53 codon 72 in exon 4 polymorphism, the risk of being sarcopenic for "Arg/"Arg genotype in NWO women is 31\% higher than normal weight lean carriers [29].

In the United States of America the NWO was present in 30 million Americans, with heightened cardiometabolic risk [80]. In Switzerland the frequency of NWO was $10.1 \%$ in women and $3.2 \%$ in men [124].

Marques-Vidal et al. [125] found that NWO women had higher blood pressure and greater prevalence of dyslipidemia and hyperglycemia than lean women did [126].

Evaluating the cardiovascular mortality risks, Sahakyan et al. demonstrated that women with NOW, with visceral adiposity had a higher mortality risk than those with similar BMI but no visceral obesity (HR, 1:48 [CI 1:35 to 1.62]) and those who were in obesity status according to BMI only (HR, 1:32 [CI 1.15 to 1.51]) [127].

Kang et al. highlighted for the first time that NWO subjects have a higher degree of vascular inflammation using 18 F-fluorodeoxyglucose positron emission tomography/ computed tomography (18 F-FDG-PET/CT) respect to normal weight lean subjects [128].

In 23.748 Chinese people the prevalence of NWO was 9.5\% for men, $6.6 \%$ for women, associated with increased cardiometabolic risks and MetS, also after excluding the effect of abdominal obesity [129]. Liu et al. showed that waist-to-height ratio (WHtR) and waist-to-hip ratio (WHR) are the optimal indicators of MetS in Chinese postmenopausal women [130]. Chinese NWO postmenopausal women in the highest WHtR tertile $(\geq 0.05)$ had a higher odds ratio for the presence of at least 2 nonadipose MetS components ( $\mathrm{p}<0.05)$ compared with NW women in the lowest tertile after adjusting for confounding factors, such as age and metabolic parameters [131]. This is the result of the clinical assessment of WHtR, which should be conducted to prevent adverse CVD risk in postmenopausal women, independently of BMI.

\section{Conclusions}

Overall, these results increasingly support the importance of defining the precursory indicators of obesity phenotypes with a view to identifying possible morbidity and mortality risk indexes, in order to establish targeted diet therapy as soon as possible, also considering possible variants genotypes found [132].

It is essential to adopt all possible strategies to be able to combat obesity, ameliorate the suffering of patients, and reduce the social and treatment costs of obesity.
Therefore, an early identification of all obesity phenotypes is fundamental, as they constitute a "vulnerable" category because, based on the indices and measures adopted to classify obesity, they are not aware of being at risk of developing pathologies linked to obesity.

Cost of illness (COI) assist policy to recognize the financial load of a disease. Obesity leads to a big expenditure on medicine care, private and public costs. It is a priority defines actions of prevention in order to save on social resources public [133].

Since obesity is a complex disease condition with much different co-morbidity, what fraction of the comorbidities is attributed to obesity has much influence on the cost calculation. If we assume that at least $10 \%$ of the adult over 18-year-old population with normal weight is actually in obesity status according the PBF, the COI of obesity would increase and the 5-6\% spend more than if they are not taken care $[134,135]$.

Treatments of severe obesity resulted in high degree of heterogeneity. In particular, Ryder et al. demonstrated that lifestyle, pharmacotherapy, or metabolic and bariatric surgery interventions ranged from -50.2 to $+12.9 \%$ of BMI reduction; therefore, it is necessary to identify new precision medicine approaches to counter obesity [136, 137].

Biochemical and body composition indices, associated with genetic analysis and the study of the inflammatory pattern, are fundamental clinical tools for the diagnosis of obesity but also to predict, with years of advance, the development of type II diabetes, cardiovascular disease and cancer $[131,138]$.

The fallout of a correct and early diagnosis of obesity will also produce lower health costs for primary and secondary prevention of the most common degenerative diseases related to it.

\section{Abbreviations}

WHO: World Health Organization; TOS: The Obesity Society; CVD: cardiovascular diseases; BMI: body mass; PBF: percentage body fat; BeW: Belarmino-Waitzberg; BF: body fat; FFM: fat free mass; BCM: body cell mass; DXA: dual X-ray absorptiometry; OP: obesity paradox; HF: hearth failure; IL: interleukin; TNF-a: tumor necrosis factor-a; NW: normal weight; NWO: normal-weight obese; MHO: metabolically healthy obese; MUO: metabolically unhealthy obese; MetS: metabolic syndrome; MONW: metabolically obese normal weight; WHtR: waist-to-height ratio; WHR: waist-to-hip ratio; COI: cost of illness.

\section{Acknowledgements}

We are indebted to Dr. Gemma Lou De Santis for language revision.

\section{Authors' contributions}

$\mathrm{ADL}$ and LDR were responsible for conceiving the ideas. All authors wrote different parts of the manuscript. All authors read and approved the final manuscript.

\section{Funding}

None. 
Availability of data and materials

Not applicable.

\section{Ethics approval and consent to participate}

Not applicable.

\section{Consent for publication}

Not applicable.

\section{Competing interests}

The authors declare that they have no competing interests.

\section{Author details}

${ }^{1}$ Section of Clinical Nutrition and Nutrigenomic, Department of Biomedicine and Prevention, University of Rome Tor Vergata, Rome, Italy. ${ }^{2}$ Department of Surgery and Medical Science, Magna Græcia University, Germaneto, Catanzaro, Italy. ${ }^{3}$ Department of Laboratory Medicine, "Tor Vergata" University Hospital, Viale Oxford 81, 00133 Rome, Italy.

Received: 28 February 2019 Accepted: 10 May 2019

Published online: 22 May 2019

\section{References}

1. Jadad AR, O'Grady L. How should health be defined? BMJ. 2008. https:// doi.org/10.1136/bmj.a2900.

2. Scully JL. What is a disease? EMBO Rep. 2004;5(7):650-3.

3. World Health Organization. International classification of impairments, disabilities, and handicaps: a manual of classification relating to the consequences of disease, published in accordance with resolution WHA29.35 of the Twenty-ninth World Health Assembly, May 1976. Geneva: World Health Organization. 1980. http://www.who.int/ iris/handle/10665/41003.

4. Committee on Diagnostic Error in Health Care; Board on Health Care Services; Institute of Medicine; The National Academies of Sciences, Engineering, and Medicine. In: Balogh EP, Miller BT, Ball JR, editors. Improving diagnosis in health care. Washington (DC): National Academies Press; 2015. p. 2.

5. Carter SM, Rogers W, Heath I, Degeling C, Doust J, Barratt A. The challenge of overdiagnosis begins with its definition. BMJ. 2015. https://doi. org/10.1136/bmj.h869.

6. Moynihan R, Doust J, Henry D. Preventing overdiagnosis: how to stop harming the healthy. BMJ. 2012. https://doi.org/10.1136/bmj.e3502.

7. Doust J, Vandvik PO, Qaseem A, Mustafa RA, Horvath AR, Frances A, Al-Ansary L, Bossuyt P, Ward RL, Kopp I, Gollogly L, Schunemann $\mathrm{H}$, Glasziou P, Guidelines International Network (G-I-N) Preventing Overdiagnosis Working Group. Guidance for modifying the definition of diseases: a checklist. JAMA Intern Med. 2017. https://doi.org/10.1001/ jamainternmed.2017.1302.

8. Golubnitschaja O, Kinkorova J, Costigliola V. Predictive, preventive and personalised medicine as the hardcore of 'Horizon 2020': EPMA position paper. EPMA J. 2014. https://doi.org/10.1186/1878-5085-5-6.

9. De Lorenzo A, Bianchi A, Maroni P, lannarelli A, Di Daniele N, lacopino L, Di Renzo L. Adiposity rather than BMI determines metabolic risk. Int J Cardiol. 2013. https://doi.org/10.1016/j.ijcard.2011.10.006.

10. Jastreboff AM, Kotz CM, Kahan S, Kelly AS, Heymsfield SB. Obesity as a disease: the obesity society 2018 position statement. Obesity (Silver Spring). 2019. https://doi.org/10.1002/oby.22378.

11. Müller MJ, Geisler C. Defining obesity as a disease. Eur J Clin Nutr. 2017. https://doi.org/10.1038/ejen.2017.155.

12. Vallgårda S, Nielsen MEJ, Hansen AKK, Cathaoir KÓ, Hartlev M, Holm L, Christensen BJ, Jensen JD, Sørensen TIA, Sandøe P. Should Europe follow the US and declare obesity a disease?: a discussion of the so-called utilitarian argument. Eur J Clin Nutr. 2017. https://doi.org/10.1038/ ejcn.2017.103.

13. Bays HE. Adiposopathy is "sick fat" a cardiovascular disease? J Am Coll Cardiol. 2011. https://doi.org/10.1016/j.jacc.2011.02.038.

14. Bays HE, González-Campoy JM, Bray GA, Kitabchi AE, Bergman DA, Schorr AB, Rodbard HW, Henry RR. Pathogenic potential of adipose tissue and metabolic consequences of adipocyte hypertrophy and increased visceral adiposity. Expert Rev Cardiovasc Ther. 2008. https:// doi.org/10.1586/14779072.6.3.343.

15. Bays H, Ballantyne C. Adiposopathy: why do adiposity and obesity cause metabolic disease? Future Lipidol. 2006. https://doi. org/10.2217/17460875.1.4.389.

16. Bays $\mathrm{H}$, Dujovne CA. Adiposopathy is a more rational treatment target for metabolic disease than obesity alone. Curr Atheroscler Rep. 2006. https://doi.org/10.1007/s11883-006-0052-6.

17. Bays H. Adiposopathy, metabolic syndrome, quantum physics, general relativity, chaos and the Theory of Everything. Expert Rev Cardiovasc Ther. 2005. https://doi.org/10.1586/14779072.3.3.393.

18. Council of the Obesity Society. Obesity as a disease: the Obesity Society Council resolution. Obesity (Silver Spring). 2008. https://doi. org/10.1038/oby.2008.246.

19. Vainio $H$, Kaaks $R$, Bianchini F. Weight control and physical activity in cancer prevention: international evaluation of the evidence. Eur J Cancer Prev. 2002;11(Suppl 2):S94-100.

20. Marmot M, Atinmo T, Byers T, Chen J, Hirohata T, Jackson A, James W, Kolonel L, Kumanyika S, Leitzmann C, Mann J, Powers H, Reddy K, Riboli E, Rivera JA, Schatzkin A, Seidell J, Shuker D, Uauy R, Willett W, Zeisel S. Food, nutrition, physical activity, and the prevention of cancer: a global perspective. 2016. http://discovery.ucl.ac.uk/4841/. Accessed 6 Sept 2016.

21. Beamish AJ, Johansson SE, Olbers T. Bariatric surgery in adolescents: what do we know so far? Scand J Surg. 2015. https://doi. org/10.1177/1457496914553150.

22. Costacurta M, Sicuro L, Di Renzo L, Condò R, De Lorenzo A, Docimo R. Childhood obesity and skeletal-dental maturity. Eur J Paediatr Dent. 2012;13(2):128-32.

23. De Lorenzo A, Romano L, Di Renzo L, Gualtieri P, Salimei C, Carrano E, Rampello T, de Miranda RC. Triponderal mass index rather than body mass index: an indicator of high adiposity in Italian children and adolescents. Nutrition. 2018. https://doi.org/10.1016/j.nut.2018.09.007.

24. Costacurta M, DiRenzo L, Sicuro L, Gratteri S, De Lorenzo A, Docimo R. Dental caries and childhood obesity: analysis of food intakes, lifestyle. Eur J Paediatr Dent. 2014:15(4):343-8.

25. Colica C, Di Renzo L, Gualtieri P, Romano L, Costa de Miranda R, De Lorenzo A, Purificato I. Development and cross-validation of predictive equation for estimating total body lean in children. Ann Ist Super Sanita. 2018. https://doi.org/10.4415/ANN_18_01_06.

26. Restivo MR, McKinnon MC, Frey BN, Hall GB, Syed W, Taylor VH. The impact of obesity on neuropsychological functioning in adults with and without major depressive disorder. PLOS ONE. 2017. https://doi. org/10.1371/journal.pone.0176898.

27. Di Renzo L, Tyndall E, Gualtieri P, Carboni C, Valente R, Ciani AS, Tonini MG, De Lorenzo A. Association of body composition and eating behavior in the normal weight obese syndrome. Eat Weight Disord. 2016. https://doi.org/10.1007/s40519-015-0215-y.

28. Gerald JJ, Seung-uk K, Nancy SCS, Stephanie AS, Luigi F, Eleanor MS. Cross-sectional and longitudinal associations between adiposity and walking endurance in adults age 60-79. J Gerontol A Biol Sci Med Sci. 2016. https://doi.org/10.1093/gerona/glw054.

29. Di Renzo L, Gratteri S, Sarlo F, Cabibbo A, Colica C, De Lorenzo A. Individually tailored screening of susceptibility to sarcopenia using p53 codon 72 polymorphism, phenotypes, and conventional risk factors. Dis Markers. 2014. https://doi.org/10.1155/2014/743634.

30. Di Renzo L, Sarlo F, Petramala L, lacopino L, Monteleone G, Colica C, De Lorenzo A. Association between - 308 G/A TNF-a polymorphism and appendicular skeletal muscle mass index as a marker of sarcopenia in normal weight obese syndrome. Dis Markers. 2013. https://doi. org/10.1155/2013/983424.

31. Vaidya V, Gangan N, Sheehan J. Impact of cardiovascular complications among patients with Type 2 diabetes mellitus: a systematic review. Expert Rev Pharmacoecon Outcomes Res. 2015. https://doi. org/10.1586/14737167.2015.1024661.

32. Zhang X, Decker FH, Luo H, Geiss LS, Pearson WS, Saaddine JB, Gregg EW, Albright A. Trends in the prevalence and comorbidities of diabetes mellitus in nursing home residents in the United States: 1995-2004. J Am Geriatr Soc. 2010. https://doi.org/10.1111/j.1532-5415.2010.02786.x.

33. Jurado J, Ybarra J, Solanas P, et al. Prevalence of cardiovascular disease and risk factors in a type 2 diabetic population of the North 
Catalonia diabetes study. J Am Acad Nurse Pract. 2009. https://doi. org/10.1111/j.1745-7599.2008.00377.x.

34. Gee ME, Janssen I, Pickett W, McAlister FA, Bancej CM, Joffres M, Johansen H, Campbell NR. Prevalence, awareness, treatment, and control of hypertension among Canadian adults with diabetes, 2007 to 2009. Can J Cardiol. 2012. https://doi.org/10.1016/j. cjca.2011.08.111.

35. Vijayaraghavan M, He G, Stoddard P, Schillinger D. Blood pressure control, hypertension, awareness, and treatment in adults with diabetes in the United States-Mexico border region. Rev Panam Salud Publica. 2010;28(3):164-73.

36. Caughey GE, Roughead EE, Vitry Al, McDermott RA, Shakib S, Gilbert AL. Comorbidity in the elderly with diabetes: Identification of areas of potential treatment conflicts. Diabetes Res Clin Pract. 2010. https:// doi.org/10.1016/j.diabres.2009.10.019.

37. Zekry D, Frangos E, Graf C, Michel JP, Gold G, Krause KH, Hermann FR, Vischer UM. Diabetes, comorbidities and increased long-term mortality in older patients admitted for geriatric inpatient care. Diabetes Metab. 2012. https://doi.org/10.1016/j.diabet.2011.10.001.

38. Poulsen MK, Henriksen JE, Dahl J, Johansen A, Møller JE, Gerke O, Vach W, Haghfelt T, Beck-Nielsen H, Høilund-Carlsen PF. Myocardial ischemia, carotid, and peripheral arterial disease and their interrelationship in type 2 diabetes patients. J Nucl Cardiol. 2009. https://doi. org/10.1007/s12350-009-9118-5.

39. Piazza G, Goldhaber SZ, Kroll A, Goldberg RJ, Emery C, Spencer FA. Venous thromboembolism in patients with diabetes mellitus. Am J Med. 2012. https://doi.org/10.1016/j.amjmed.2011.12.004.

40. Chyun D, Vaccarino V, Murillo J, Young LH, Krumholz HM. Acute myocardial infarction in the elderly with diabetes. Heart Lung. 2002;31(5):327-39.

41. McEwen LN, Karter AJ, Waitzfelder BE, Crosson JC, Marrero DG, Mangione CM, Herman WH. Predictors of mortality over 8 years in type 2 diabetic patients: Translating Research Into Action for Diabetes (TRIAD). Diabetes Care. 2012. https://doi.org/10.2337/dc11-2281.

42. American Diabetes Association. Economic costs of diabetes in the U.S. in 2012. Diabetes Care. 2013. https://doi.org/10.2337/dc12-2625.

43. Braun KF, Otter W, Sandor SM, Standl E, Schnell O. All-cause in-hospital mortality and comorbidity in diabetic and non-diabetic patients with stroke. Diabetes Res Clin Pract. 2012. https://doi.org/10.1016/j. diabres.2012.04.016.

44. Angelantonio E, Bhupathiraju SN, Wormser D, Gao P, Kaptoge S, BerringtondeGonzalez A, Cairns BJ, Huxley R, Jackson CL, Joshy G, Lewington S, Manson JE, Murphy N, Patel AV, Samet JM, Woodward M, Zheng W, Zhou M, Bansal N, Barricarte A, Carter B, Cerhan JR, Smith GD, Fang X, Franco OH, Green J, Halsey J, Hildebrand JS, Jung KJ, Korda RJ, McLerran DF, Moore SC, OKeeffe LM, Paige E, Ramond A, Reeves GK, Rolland B, Sacerdote C, Sattar N, Sofianopoulou E, Stevens J, Thun M, Ueshima H, Yang L, Yun YD, Willeit P, Banks E, Beral V, Chen Z, Gapstur SM, Gunter MJ, Hartge P, Jee SH, Lam TH, Peto R, Potter JD, Willett WC, Thompson SG, Danesh J, Hu FB. Body-mass index and all-cause mortality: individual-participant-data meta-analysis of 239 prospective studies in four continents. Lancet. 2016. https://doi. org/10.1016/S0140-6736(16)30175-1.

45. Physical status: the use and interpretation of anthropometry. Report of a WHO Expert Committee. World Health Organ Tech Rep Ser. 1995;854:1-452.

46. Flegal KM. Commentary: the quest for weight standards. Int J Epidemiol. 2010. https://doi.org/10.1093/ije/dyq124.

47. Bray GA, Heisel WE, Afshin A, Jensen MD, Dietz WH, Long M, Kushner RF, Daniels SR, Wadden TA, Tsai AG, Hu FB, Jakicic JM, Ryan DH, Wolfe $B M$, Inge TH. The science of obesity management: an endocrine society scientific statement. Endocr Rev. 2018. https://doi.org/10.1210/ er.2017-00253.

48. Flegal KM, Kruszon-Moran D, Carroll MD, Fryar CD, Ogden CL. Trends in obesity among adults in the United States, 2005 to 2014. JAMA. 2016. https://doi.org/10.1001/jama.2016.6458.

49. Obesity: preventing and managing the global epidemic. Report of a WHO consultation. World Health Organ Tech Rep Ser. 2000;894: $1-253$.
50. lacobini C, Pugliese G, Blasetti Fantauzzi C, Federici M, Menini S. Metabolically healthy versus metabolically unhealthy obesity. Metabolism. 2019. https://doi.org/10.1016/..metabol.2018.11.009.

51. Neeland IJ, Poirier P, Després JP. Cardiovascular and metabolic heterogeneity of obesity: clinical challenges and implications for management. Circulation. 2018. https://doi.org/10.1161/CIRCULATIONAHA.117.02961 7.

52. Oliveros E, Somers VK, Sochor O, Goel K, Lopez-Jimenez F. The concept of normal weight obesity. Prog Cardiovasc Dis. 2014. https://doi. org/10.1016/j.pcad.2013.10.003.

53. Bergman RN, Stefanovski D, Buchanan TA, Sumner AE, Reynolds JC, Sebring NG, Xiang AH, Watanabe RM. A better index of body adiposity. Obesity (Silver Spring). 2011. https://doi.org/10.1038/oby.2011.38.

54. Segheto W, Coelho FA, Cristina Guimarães da Silva D, Hallal PC, Marins JC, Ribeiro AQ, Pessoa MC, Morais SH, Longo GZ. Validity of body adiposity index in predicting body fat in Brazilians adults. Am J Hum Biol. 2017. https://doi.org/10.1002/ajhb.22901.

55. Belarmino G, Torrinhas RS, Sala P, Horie LM, Damiani L, Lopes NC, Heymsfield SB, Waitzberg DL. A new anthropometric index for body fat estimation in patients with severe obesity. BMC Obes. 2018. https://doi. org/10.1186/s40608-018-0202-8.

56. Bourgeois B, Fan B, Johannsen N, Gonzalez MC, Ng BK, Sommer MJ, Shepherd JA, Heymsfield SB. Improved strength prediction combining clinically available measures of skeletal muscle mass and quality. J Cachexia Sarcopenia Muscle. 2018. https://doi.org/10.1002/jcsm.12353.

57. Sun Q, van Dam RM, Spiegelman D, Heymsfield SB, Willett WC, Hu FB. Comparison of dual-energy $X$-ray absorptiometric and anthropometric measures of adiposity in relation to adiposity-related biologic factors. Am J Epidemiol. 2010. https://doi.org/10.1093/aje/kwq306.

58. Thibault R, Pichard C. The evaluation of body composition: a useful tool for clinical practice. Ann Nutr Metab. 2012. https://doi. org/10.1159/000334879.

59. Li C, Ford ES, Zhao G, Balluz LS, Giles WH. Estimates of body composition with dual-energy X-ray absorptiometry in adults. Am J Clin Nutr. 2009. https://doi.org/10.3945/ajen.2009.28141.

60. Semelka RC, Armao DM, Elias J Jr, Huda W. Imaging strategies to reduce the risk of radiation in $\mathrm{CT}$ studies, including selective substitution with MRI. J Magn Reson Imaging. 2007;25(5):900-9.

61. De Lorenzo A, Deurenberg P, Pietrantuono M, Di Daniele N, Cervelli V, Andreoli A. How fat is obese? Acta Diabetol. 2003:40(Suppl 1):S254-7.

62. De Lorenzo A, Nardi A, lacopino L, Domino E, Murdolo G, Gavrila C, Minella D, Scapagnini G, Di Renzo L. A new predictive equation for evaluating women body fat percentage and obesity-related cardiovascular disease risk. J Endocrinol Invest. 2014. https://doi.org/10.1007/ s40618-013-0048-3.

63. Sharma AM, Kushner R. A proposed clinical staging system for obesity. Int J Obes (Lond). 2009. https://doi.org/10.1038/ijo.2009.2.

64. Padwal Raj S, Pajewski Nicholas M, Allison David B, Sharma Arya M. Using the Edmonton obesity staging system to predict mortality in a population-representative cohort of people with overweight and obesity. CMAJ. 2011. https://doi.org/10.1503/cmaj.110387.

65. Hebebrand J, Holm JC, Woodward E, Baker JL, Blaak E, Durrer Schutz D, Farpour-Lambert NJ, Frühbeck G, Halford JGC, Lissner L, Micic D, Mullerova D, Roman G, Schindler K, Toplak H, Visscher TLS, Yumuk V. A Proposal of the European Association for the Study of Obesity to Improve the ICD-11 diagnostic criteria for obesity based on the three dimensions etiology, degree of adiposity and health risk. Obes Facts. 2017. https://doi.org/10.1159/000479208.

66. Gema F, Luca B, Luca B, Dror D, Volkan Y, Gijs HG, Johannes H, Jason GCH, Nathalie JF-L, Ellen EB, Euan W, Hermann T. The ABCD of obesity: an EASO position statement on a diagnostic term with clinical and scientific implications. Obes Facts. 2019. https://doi.org/10.1159/00049 7124.

67. Gordon-Larsen P, Heymsfield SB. Obesity as a disease, not a behavior. Circulation. 2018. https://doi.org/10.1161/CIRCULATIONAHA.118.03278 0.

68. Snitker S. Use of body fatness cutoff points. Mayo Clin Proc. 2010. https ://doi.org/10.4065/mcp.2010.0583.

69. Fantuzzi G. Adipose tissue, adipokines, and inflammation. J Allergy Clin Immunol. 2005;115(5):911-9. 
70. Ulijaszek SJ, Kerr DA. Anthropometric measurement error and the assessment of nutritional status. Br J Nutr. 1999;82(3):165-77. Br J Nutr. 2000;83(1):95

71. Nickerson BS, Esco MR, Bishop PA, Fedewa MV, Snarr RL, Kliszczewicz BM, Park KS. Validity of BMI-based body fat equations in men and women: a 4-compartment model comparison. J Strength Cond Res. 2018. https://doi.org/10.1519/JSC.0000000000001774.

72. Cawley J, Maclean JC, Hammer M, Wintfeld N. Reporting error in weight and its implications for bias in economic models. Econ Hum Biol. 2015. https://doi.org/10.1016/j.ehb.2015.07.001.

73. Forbes GB. Human body composition. Growth, aging, nutrition, and activity. New York: Springer; 1987.

74. Pérez-Chirinos Buxadé C, Solà-Perez T, Castizo-Olier J, CarrascoMarginet M, Roy A, Marfell-Jones M, Irurtia A. Assessing subcutaneous adipose tissue by simple and portable field instruments: skinfolds versus A-mode ultrasound measurements. PLoS ONE. 2018. https://doi. org/10.1371/journal.pone.0205226.

75. Cui Z, Stevens J, Truesdale KP, Zeng D, French S, Gordon-Larsen P. Prediction of body mass index using concurrently self-reported or previously measured height and weight. PLOS ONE. 2016. https://doi. org/10.1371/journal.pone.0167288.

76. De Lorenzo A, Soldati L, Sarlo F, Calvani M, Di Lorenzo N, Di Renzo L. New obesity classification criteria as a tool for bariatric surgery indication. World J Gastroenterol. 2016. https://doi.org/10.3748/wjg.v22. i2.681.

77. Kyle UG, Bosaeus I, De Lorenzo AD, Deurenberg P, Elia M, Gómez JM, Heitmann BL, Kent-Smith L, Melchior JC, Pirlich M, Scharfetter H, Schols AM, Pichard C, Composition of the ESPEN Working Group. Bioelectrical impedance analysis - part I: review of principles and methods. Clin Nutr. 2004;23(5):1226-43.

78. Kyle UG, Bosaeus I, De Lorenzo AD, Deurenberg P, Elia M, Manuel Gómez J, Lilienthal Heitmann B, Kent-Smith L, Melchior JC, Pirlich M, Scharfetter H, Schols A, Pichard C, ESPEN. Bioelectrical impedance analysis-part II: utilization in clinical practice. Clin Nutr. 2004;23(6):1430-53.

79. Rodriguez-Sanchez N, Galloway SD. Errors in dual energy X-ray absorptiometry estimation of body composition induced by hypohydration. Int J Sport Nutr Exerc Metab. 2015. https://doi.org/10.1123/ijsne m.2014-0067.

80. Zimmerman JE, Kramer AA, McNair DS, Malila FM. Acute Physiology and Chronic Health Evaluation (APACHE) IV: hospital mortality assessment for today's critically ill patients. Crit Care Med. 2006;34(5):1297-310.

81. Johnson AE, Kramer AA, Clifford GD. A new severity of illness scale using a subset of acute physiology and chronic health evaluation data elements shows comparable predictive accuracy. Crit Care Med. 2013. https://doi.org/10.1097/CCM.0b013e31828a24fe.

82. Vincent JL, Moreno R, Takala J, Willatts S, De Mendonça A, Bruining H, Reinhart CK, Suter PM, Thijs LG. The SOFA (Sepsis-related Organ Failure Assessment) score to describe organ dysfunction/failure. On behalf of the Working Group on Sepsis-Related Problems of the European Society of Intensive Care Medicine. Intensive Care Med. 1996;22(7):707-10.

83. Moreno RP, Metnitz PG, Almeida E, Jordan B, Bauer P, Campos RA, lapichino G, Edbrooke D, Capuzzo M, Le Gall JR; SAPS 3 Investigators. SAPS 3-from evaluation of the patient to evaluation of the intensive care unit. Part 2: development of a prognostic model for hospital mortality at ICU admission. Intensive Care Med. 2005;31(10):1345-55. Erratum in: Intensive Care Med. 2006;32(5):796.

84. Lavie CJ, Sharma A, Alpert MA, De Schutter A, Lopez-Jimenez F, Milani $\mathrm{RV}$, Ventura HO. Update on obesity and obesity paradox in heart failure. Prog Cardiovasc Dis. 2016. https://doi.org/10.1016/j.pcad.2015.12.003.

85. Kramer A. Different type of "obesity paradox". Critical Care Medicine. 2019. https://doi.org/10.1097/CCM.0000000000003575.

86. Deliberato RO, Serpa Neto A, Komorowski M, Stone DJ, Ko SQ, Bulgarelli L, Rodrigues Ponzoni C, de Freitas Chaves RC, Celi LA, Johnson AEW. An evaluation of the influence of body mass index on severity scoring. Crit Care Med. 2019. https://doi.org/10.1097/CCM.0000000000003528.

87. Horwich TB, Fonarow GC, Clark AL. Obesity and the obesity paradox in heart failure. Prog Cardiovasc Dis. 2018. https://doi.org/10.1016/j. pcad.2018.05.005

88. Bozkurt B, Aguilar D, Deswal A, Dunbar SB, Francis GS, Horwich T, Jessup M, Kosiborod M, Pritchett AM, Ramasubbu K, Rosendorff C, Yancy C, American Heart Association Heart Failure and Transplantation
Committee of the Council on Clinical Cardiology; Council on Cardiovascular Surgery and Anesthesia; Council on Cardiovascular and Stroke Nursing; Council on Hypertension; and Council on Quality and Outcomes Research. Contributory risk and management of comorbidities of hypertension, obesity, diabetes mellitus, hyperlipidemia, and metabolic syndrome in chronic heart failure: a scientific statement from the american heart association. Circulation. 2016;134(23):e535-78.

89. Kenchaiah S, Pocock SJ, Wang D, Finn PV, Zornoff LA, Skali H, Pfeffer MA, Yusuf S, Swedberg K, Michelson EL, Granger CB, McMurray JJ, Solomon SD; CHARM Investigators. Body mass index and prognosis in patients with chronic heart failure: insights from the Candesartan in Heart failure: assessment of reduction in mortality and morbidity (CHARM) program. Circulation. 2007;116(6):627-36. Erratum in: Circulation. 2007;116(6):e136.

90. Lavie CJ, McAuley PA, Church TS, Milani RV, Blair SN. Obesity and cardiovascular diseases: implications regarding fitness, fatness, and severity in the obesity paradox. J Am Coll Cardiol. 2014. https://doi. org/10.1016/j.jacc.2014.01.022.

91. De Lorenzo A, Del Gobbo V, Premrov MG, Bigioni M, Galvano F, Di Renzo L. Normal-weight obese syndrome: early inflammation? Am J Clin Nutr. 2007;85(1):40-5.

92. Abenavoli L, Luigiano C, Guzzi PH, Milic N, Morace C, Stelitano L, Consolo P, Miraglia S, Fagoonee S, Virgilio C, Luzza F, De Lorenzo A, Pellicano R. Serum adipokine levels in overweight patients and their relationship with non-alcoholic fatty liver disease. Panminerva Med. 2014;56(2):189-93.

93. Vecchié A, Dallegri F, Carbone F, Bonaventura A, Liberale L, Portincasa P, Frühbeck G, Montecucco F. Obesity phenotypes and their paradoxical association with cardiovascular diseases. Eur J Intern Med. 2018. https://doi.org/10.1016/j.ejim.2017.10.020.

94. Neeland IJ, Gupta S, Ayers CR, Turer AT, Rame JE, Das SR, Berry JD, Khera A, McGuire DK, Vega GL, Grundy SM, de Lemos JA, Drazner MH. Relation of regional fat distribution to left ventricular structure and function. Circ Cardiovasc Imaging. 2013. https://doi.org/10.1161/ CIRCIMAGING.113.000532.

95. Naderi N, Kleine CE, Park C, Hsiung JT, Soohoo M, Tantisattamo E, Streja E, Kalantar-Zadeh K, Moradi H. Obesity paradox in advanced kidney disease: from bedside to the bench. Prog Cardiovasc Dis. 2018. https://doi.org/10.1016/j.pcad.2018.07.001.

96. Kalantar-Zadeh K, Streja E, Kovesdy CP, Oreopoulos A, Noori N, Jing J, Nissenson AR, Krishnan M, Kopple JD, Mehrotra R, Anker SD. The obesity paradox and mortality associated with surrogates of body size and muscle mass in patients receiving hemodialysis. Mayo Clin Proc. 2010. https://doi.org/10.4065/mcp.2010.0336.

97. Costanzo P, Cleland JG, Pellicori P, Clark AL, Hepburn D, Kilpatrick ES, Perrone-Filardi P, Zhang J, Atkin SL. The obesity paradox in type 2 diabetes mellitus: relationship of body mass index to prognosis: a cohort study. Ann Intern Med. 2015. https://doi.org/10.7326/ M14-1551.

98. Zhao W, Katzmarzyk PT, Horswell R, Wang Y, Li W, Johnson J, Heymsfield SB, Cefalu WT, Ryan DH, Hu G. Body mass index and the risk of all-cause mortality among patients with type 2 diabetes mellitus. Circulation. 2014. https://doi.org/10.1161/CIRCULATIONAHA.114.009098.

99. Han SJ, Boyko EJ. The evidence for an obesity paradox in type 2 diabetes mellitus. Diabetes Metab J. 2018. https://doi.org/10.4093/ dmj.2018.0055.

100. Lajous M, Banack HR, Kaufman JS, Hernán MA. Should patients with chronic disease be told to gain weight? The obesity paradox and selection bias. Am J Med. 2015. https://doi.org/10.1016/j.amjme d.2014.10.043.

101. Batsis JA, Mackenzie TA, Emeny RT, Lopez-Jimenez F, Bartels SJ. Low lean mass with and without obesity, and mortality: results from the 1999-2004 national health and nutrition examination survey. J Gerontol A Biol Sci Med Sci. 2017. https://doi.org/10.1093/gerona/gl×002.

102. Chackrewarthy S, Gunasekera D, Pathmeswaren A, Wijekoon CN, Ranawaka UK, Kato N, Takeuchi F, Wickremasinghe AR. A comparison between revised NCEP ATP III and IDF definitions in diagnosing metabolic syndrome in an urban sri lankan population: the ragama health study. ISRN Endocrinol. 2013;2013:320176. https://doi. org/10.1155/2013/320176. 
103. Mason EE, Doherty C, Maher JW, Scott DH, Rodriguez EM, Blommers TJ. Super obesity and gastric reduction procedures. Gastroenterol Clin North Am. 1987;6:495-502.

104. Antonini-Canterin F, Mateescu AD, Vriz O, La Carrubba S, Di Bello V, Carerj S, Zito C, Sparacino L, Marzano B, Usurelu C, Ticulescu R, Ginghină C, Nicolosi GL, Popescu BA. Cardiac structure and function and insulin resistance in morbidly obese patients: does superobesity play an additional role? Cardiology. 2014. https://doi. org/10.1159/000355260.

105. Wolf AM, Buffington C, Beisiegel U. Comparison of metabolic risk factors between severely and very severely obese patients. Obesity. 2006;14:2177-83.

106. Madeira FB, Silva AA, Veloso HF, Goldani MZ, Kac G, Cardoso VC, Bettiol $\mathrm{H}$, Barbieri MA. Normal weight obesity is associated with metabolic syndrome and insulin resistance in young adults from a middle-income country. PLoS ONE. 2013. https://doi.org/10.1371/ journal.pone.0060673.

107. Ruderman N, Chisholm D, Pi-Sunyer X, Schneider S. The metabolically obese, normal-weight individual revisited. Diabetes. 1998:47(5):699-713.

108. Bays H. Central obesity as a clinical marker of adiposopathy; increasedvisceral adiposity as a surrogate marker for global fat dysfunction. Curr Opin Endocrinol Diabetes Obes. 2014. https://doi. org/10.1097/MED.0000000000000093.

109. Karelis AD, Faraj M, Bastard JP, St-Pierre DH, Brochu M, Prud'homme $D$, Rabasa-Lhoret $R$. The metabolically healthy but obese individual presents a favorable inflammation profile. J Clin Endocrinol Metab. 2005;90(7):4145-50.

110. Shaharyar S, Roberson LL, Jamal O, Younus A, Blaha MJ, Ali SS, Zide K, Agatston AA, Blumenthal RS, Conceição RD, Santos RD, Nasir K. Obesity and metabolic phenotypes (metabolically healthy and unhealthy variants) are significantly associated with prevalence of elevated C-reactive protein and hepatic steatosis in a large healthy Brazilian population. J Obes. 2015. https://doi.org/10.1155/2015/178526.

111. lacobini C, Pugliese G, Blasetti Fantauzzi C, Federici M, Menini S. Metabolically healthy versus metabolically unhealthy obesity. Metabolism. 2019. https://doi.org/10.1016/j.metabol.2018.11.009

112. Berezina A, Belyaeva O, Berkovich O, Baranova E, Karonova T, Bazhenova E, Brovin D, Grineva E, Shlyakhto E. Prevalence, risk factors, and genetic traits in metabolically healthy and unhealthy obese individuals. Biomed Res Int. 2015. https://doi.org/10.1155/2015/548734.

113. Camhi SM, Crouter SE, Hayman LL, Must A, Lichtenstein AH. Lifestyle behaviors in metabolically healthy and unhealthy overweight and obese women: a preliminary study. PLoS ONE. 2015. https://doi. org/10.1371/journal.pone.0138548.

114. Chang Y, Kim BK, Yun KE, Cho J, Zhang Y, Rampal S, Zhao D, Jung HS, Choi Y, Ahn J, Lima JA, Shin H, Guallar E, Ryu S. Metabolically-healthy obesity and coronary artery calcification. J Am Coll Cardiol. 2014. https://doi.org/10.1016/j.jacc.2014.03.042.

115. Cembrowska P, Stefańska A, Odrowąz-Sypniewska G. Obesity phenotypes: normal-weight individuals with metabolic disorders versus metabolically healthy obese. Med Res J. 2016. https://doi. org/10.5603/MRJ.2016.0016.

116. Argilés JM, López-Soriano J, Almendro V, Busquets S, López-Soriano FJ. Cross-talk between skeletal muscle and adipose tissue: a link with obesity? Med Res Rev. 2005;25(1):49-65.

117. Lee SH, Han K, Yang HK, Kim HS, Cho JH, Kwon HS, Park YM, Cha BY, Yoon KH. A novel criterion for identifying metabolically obese but normal weight individuals using the product of triglycerides and glucose. Nutr Diabetes. 2015. https://doi.org/10.1038/nutd.2014.46.

118. De Lorenzo A, Martinoli R, Vaia F, Di Renzo L. Normal weight obese (NWO) women: an evaluation of a candidate new syndrome. Nutr Metab Cardiovasc Dis. 2006;16(8):513-23.

119. Di Renzo L, Bigioni M, Bottini FG, Del Gobbo V, Premrov MG, Cianci R, De Lorenzo A. Normal Weight Obese syndrome: role of single nucleotide polymorphism of IL-1 5Ralpha and MTHFR 677C-> T genes in the relationship between body composition and resting metabolic rate. Eur Rev Med Pharmacol Sci. 2006:10(5):235-45.

120. Di Renzo L, Del Gobbo V, Bigioni M, Premrov MG, Cianci R, De Lorenzo A. Body composition analyses in normal weight obese women. Eur Rev Med Pharmacol Sci. 2006:10(4):191-6.
121. Bray GA, Kim KK, Wilding JPH, World Obesity Federation. Obesity: a chronic relapsing progressive disease process. A position statement of the World Obesity Federation. Obes Rev. 2017. https://doi. org/10.1111/obr.12551.

122. Di Renzo L, Galvano F, Orlandi C, Bianchi A, Di Giacomo C, La Fauci L, Acquaviva R, De Lorenzo A. Oxidative stress in normal-weight obese syndrome. Obesity (Silver Spring). 2010; https://doi.org/10.1038/ oby.2010.50. Erratum in Obesity (Silver Spring). 2010;18(12):2401.

123. Di Renzo L, Bigioni M, Del Gobbo V, Premrov MG, Barbini U, Di Lorenzo N, De Lorenzo A. Interleukin-1 (IL-1) receptor antagonist gene polymorphism in normal weight obese syndrome: relationship to body composition and IL-1 alpha and beta plasma levels. Pharmacol Res. 2007:55(2):131-8.

124. Marques-Vidal P, Chiolero A, Paccaud F. Large differences in the prevalence of normal weight and obesity using various cut-offs for excess body fat. E Spen Eur E J Clin Nutr Metab. 2008. https://doi. org/10.1016/j.eclnm.2008.05.003.

125. Marques-Vidal P, Pécoud A, Hayoz D, Paccaud F, Mooser V Waeber $G$, Vollenweider P. Normal weight obesity: relationship with lipids, glycaemic status, liver enzymes and inflammation. Nutr Metab Cardiovasc Dis. 2010. https://doi.org/10.1016/j.numecd.2009.06.001.

126. Nakao K, Nakata K, Ohtsubo N, Maeda M, Moriuchi T, Ichikawa T, Hamasaki K, Kato Y, Eguchi K, Yukawa K, Ishii N. Association between nonalcoholic fatty liver, markers of obesity, and serum leptin level in young adults. Am J Gastroenterol. 2002;97(7):1796-801.

127. Sahakyan KR, Somers VK, Rodriguez-Escudero JP, Hodge DO, Carter RE, Sochor O, Coutinho T, Jensen MD, Roger VL, Singh P, Lopez-Jimenez F. Normal-weight central obesity: implications for total and cardiovascular mortality. Ann Intern Med. 2015. https://doi.org/10.7326/ m14-2525.

128. Kang S, Kyung C, Park JS, Kim S, Lee SP, Kim MK, Kim HK, Kim KR, Jeon TJ, Ahn CW. Subclinical vascular inflammation in subjects with normal weight obesity and its association with body fat: an 18 F-FDG-PET/CT study. Cardiovasc Diabetol. 2014. https://doi. org/10.1186/1475-2840-13-70

129. Jia A, Xu S, Xing Y, Zhang W, Yu X, Zhao Y, Ming J, Ji Q. Prevalence and cardiometabolic risks of normal weight obesity in Chinese population: a nationwide study. Nutr Metab Cardiovasc Dis. 2018. https:// doi.org/10.1016/j.numecd.2018.06.015.

130. Liu P, Ma F, Lou H, Zhu Y. Utility of obesity indices in screening Chinese postmenopausal women for metabolic syndrome. Menopause. 2014. https://doi.org/10.1097/gme.0b013e3182a170be.

131. Liu PJ, Ma F, Lou HP, Zhu YN. Normal-weight central obesity is associated with metabolic disorders in Chinese postmenopausal women. Asia Pac J Clin Nutr. 2017. https://doi.org/10.6133/apjcn.052016.08.

132. Di Daniele N, Noce A, Vidiri MF, Moriconi E, Marrone G, AnnicchiaricoPetruzzelli M, Durso G, Tesauro M, Rovella V, De Lorenzo A. Impact of Mediterranean diet on metabolic syndrome, cancer and longevity. Oncotarget. 2017. https://doi.org/10.18632/oncotarget.13553.

133. Tremmel M, Gerdtham UG, Nilsson PM, Saha S. Economic burden of obesity: a systematic literature review. Int J Environ Res Public Health. 2017. https://doi.org/10.3390/ijerph14040435.

134. Merra G, Miranda R, Barrucco S, Gualtieri P, Mazza M, Moriconi E, Marchetti M, Chang TF, De Lorenzo A, Di Renzo L. Very-lowcalorie ketogenic diet with aminoacid supplement versus very low restricted-calorie diet for preserving muscle mass during weight loss: a pilot double-blind study. Eur Rev Med Pharmacol Sci. 2016;20(12):2613-21.

135. Colica C, Merra G, Gasbarrini A, De Lorenzo A, Cioccoloni G, Gualtieri P, Perrone MA, Bernardini S, Bernardo V, Di Renzo L, Marchetti M. Efficacy and safety of very-low-calorie ketogenic diet: a double blind randomized crossover study. Eur Rev Med Pharmacol Sci. 2017;21(9):2274-89.

136. Di Renzo L, Carbonelli MG, Bianchi A, lacopino L, Fiorito R, Di Daniele N, De Lorenzo A. Body composition changes after laparoscopic adjustable gastric banding: what is the role of $-174 \mathrm{G}>\mathrm{C}$ interleukin-6 promoter gene polymorphism in the therapeutic strategy? Int J Obes (Lond). 2012. https://doi.org/10.1038/ijo.2011.132.

137. Ryder JR, Kaizer AM, Jenkins TM, Kelly AS, Inge TH, Shaibi GQ. Heterogeneity in response to treatment of adolescents with severe obesity: 
the need for precision obesity medicine. Obesity (Silver Spring). 2019. https://doi.org/10.1002/oby.22369.

138. Andreoli A, De Lorenzo A, Cadeddu F, lacopino L, Grande M. New trends in nutritional status assessment of cancer patients. Eur Rev Med Pharmacol Sci. 2011;15(5):469-80.

\section{Publisher's Note}

Springer Nature remains neutral with regard to jurisdictional claims in published maps and institutional affiliations.
Ready to submit your research? Choose BMC and benefit from:

- fast, convenient online submission

- thorough peer review by experienced researchers in your field

- rapid publication on acceptance

- support for research data, including large and complex data types

- gold Open Access which fosters wider collaboration and increased citations

- maximum visibility for your research: over 100M website views per year

At BMC, research is always in progress.

Learn more biomedcentral.com/submissions 